\title{
ASSESSING THE IMPACT OF PUBLIC FUNDING AND TAX INCENTIVES IN RUSSIA: RECIPIENT ANALYSIS AND ADDITIONALITY EFFECTS EVALUATION'
}

YURI SIMACHEV, MIKHAIL KUZYK AND NIKOLAY ZUDIN

\section{ABSTRACT}

$\mathrm{S}$ 0 far a considerable number of studies have used the concept of additionality as basic evaluation approach but none of them paid attention to additionality effects of the Russian innovation policy yet. In this study we performed a microeconomic evaluation of the industrial firms' public innovation support in Russia focusing on its two key toolbox elements: direct funding and tax incentives. Based on the data from a questionnaire survey of top executives of Russian manufacturing firms from 2015 we identified and evaluated the profiles and the performance of recipients of direct funding and tax incentives. We also assessed the "relative" additionality - the additionality of a concrete instrument for a particular firm relative to all other used instruments with propensity score matching. The results show that generally Russian industrial innovation policy tends to target sufficiently large and long-operating companies. In terms of effects we have confirmed not only the importance of the fiscal support in providing main aspects of additionality but also its significance in crowding-out private investment. Our results suggest tax incentives do hardly contribute to additionality of any kind which is especially unusual regarding input additionality. One should also point out a relatively small impact of public support on science-business cooperation which is quite unexpected in view of the substantial effort provided by the Russian government in enhancing its development.

\section{INTRODUCTION}

In recent years the attention to innovation policy evaluation, particularly as a means of learning and also as a search for best practice, has intensified in many countries. What has been successful in one country may be counterproductive in the other, so the problem identification should be combined with certain „experiments" over solution methods combined with learning processes development (Rodrik 2008; Chaminade et al. 2009). By now an extensive experience in assessing the impact of public policies on fostering companies' innovation activities has been accumulated. There is also significant progress in the development of methodologies concerning the assessment of science-technology and innovation policies (Crespi et al. 2011). Objectives of the innovation policy evaluation have become more complex due to the need of recording a substantial amount of different factors and effects, including non-economic ones. The evolution of evaluation techniques develops in several directions (OECD 2012):

(1) establishment of frameworks and conditions, formation of the evaluation culture, and - sometimes - the development of assessment legislation;

(2) expansion of assessing institutions and their coordination, distribution and improvement of assessment practices;

(3) formation of the base and infrastructure for evaluation - determination of standards and methodologies, combining assessment with Key Performance Indicators (KPI), accumulation of policy implementation data, support for the evaluation expert community.

The following features of a modern evaluation practice of innovative instruments can be distinguished:

(1) regular assessment, cross-country comparison of results;

(2) long observation periods (over 10 years), maintenance of extensive detailed statistical databases used for performance evaluations; openness of assessment procedures to capture new effects.

(3) the complexity and ambiguity of estimates (e.g. considering substitution effect), presence of significant time lags over output effects (4-6 years), high heterogeneity of the impact of incentive mechanisms; substantial econometric problems; preparation and submission of guidelines on principles and problems of evaluation;

(4) openness, publicity of assessment results; practical use of the assessment results for decision-making at government level - the spread of best practices; drawing lessons: in particular, making decisions to stop, clarify or expand various programs, mechanisms and instruments aimed at fostering innovation activity

It must be admitted that the Russian public innovation policy evaluation system in comparison with the best foreign examples turns out to be quite imperfect and unbalanced - due to the excessive emphasis on direct results of support and lack of attention to the process of drawing lessons. 


\section{CONCEPT OF ADDITIONALITY: MAIN POINTS}

In recent years the concept of additionality has become the basic evaluation approach of the innovation policy toolbox. In the context of government intervention the notion of additionality involves a comparison of the real situation of receiving government support with a hypothetical scenario of what would have happened if no support had been provided.

The central element of the additionality concept is the change in specific indicators and company characteristics achieved thanks to gov- ernment support. For this reason additionality is often classified by the type of considered indicators and thus is divided into input, output and behavioral additionality. It must be added that in economic literature a significant portion of innovative development problems lies in the features of economic agents innovative behavior: lack of responsiveness to new knowledge, low level of cooperative activities etc. (Gok, Edler 2011). Thus, behavioral additionality should be considered more closely. Also more detailed subclasses of each type of additionality exist, which are briefly represented in figure 1. To save time we will not dig into them but instead would highlight some important points concerning the basic concept of additionality.

Figure 1 - Main types of additionality

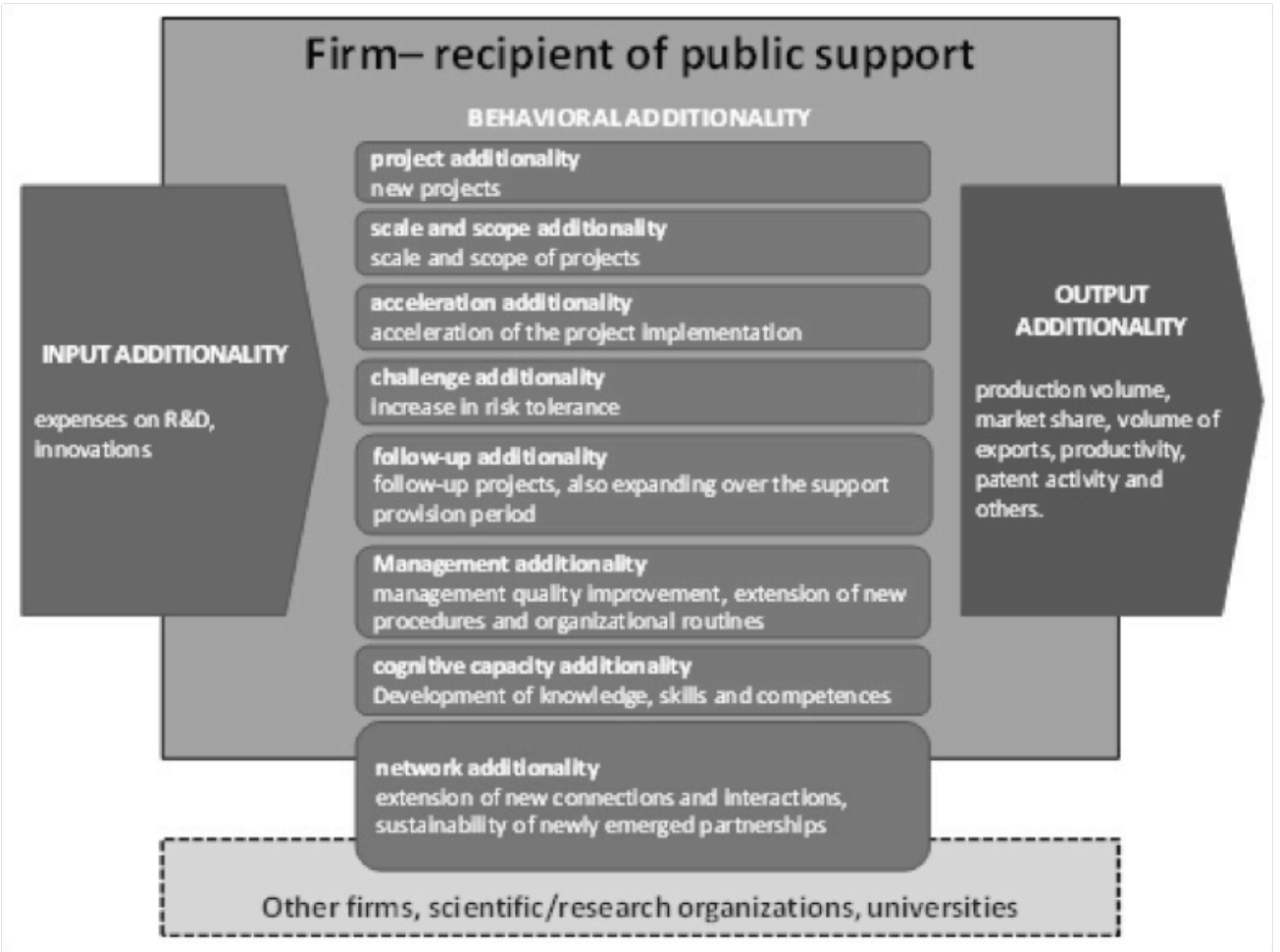

Sources: based on Buisseret et al. (1995); Georghiou (1997, 2002); Bach, Matt (2002); Georghiou et al. (2002); Rye (2002); Falk (2004); Georghiou, Clarysse (2006); Idea Consult (2006); Hsu et al. (2009); Gok (2010); Roper, Hewitt-Dundas (2012); Viljamaa et al. (2013); Wanzenbock et al. (2013); Lohmann (2014); Neicu et al. (2014)

In general, along with the main and obvious advantage of the additionality concept which lies in operating with "clean" results of public support not being achieved in the absence of the latter, one can identify a number of other important arguments in favor of this approach:

- a wide range of considered effects, including hardly formalized "quality" results of support, such as development of partnerships and competences;

- consideration of not only the direct influence of public support on a recipient, but also of the indirect impact on his/her partners in science-industrial cooperation;

- consideration of government support effects not only in the period of its provision but also after its termination is essential, firstly, to test the robustness of the results and, secondly, due to the fact that these effects often occur with a significant time lag, sometimes even a few years after provision of government support (Lopez-Acevedo, Tan 2010; Crespi et al. 2011a). 
Thus, the use of the additionality concept as the basis for the analysis of public support effectiveness enables to minimize the risks of overvaluation (due to the orientation on a net effect) and of undervaluation (what is even more important from the standpoint of identifying and disseminating best practices).

\section{CONTEMPORARY EMPIRICAL EVIDENCE ON PUBLIC SUPPORT ADDITIONALITY: BRIEF OVERVIEW}

So far a considerable number of studies assessing the effects of innovation policy on firms' activity with the use of the concept of additionality has taken place. However, none of the known studies paid attention to additionality of the Russian innovation policy. In most of them the objects of analysis were various instruments of government funding solely or (more rarely) financial support for innovation in any form as the direction of the public innovation policy. Making no claim to cover all the existent empirical evidence on additionality, we, nevertheless, can identify some common features and patterns regarding the additionality of financial support on the basis of the findings of about thirty studies.

Input and output effects of public support as well as network additionality became most often subjects of analysis (figure 2). Three other types of behavioral additionality - acceleration, follow-up and challenge - in contrast, have relatively rarely attracted the attention of researchers. Finally, despite the fact that cognitive capacity additionality is often considered in theoretical works, in practice it is usually either not included in the scope of the empirical analysis or considered as a part of the followup or management additionality.
In most cases the results obtained by the researchers confirmed the presence of different additionality effects. However, there are important single reverse examples.

For instance, the study of Marzucchi, Montresor (2013) dedicated to the analysis of the results of financial support provided at regional and national levels for companies' innovation activities in manufacturing sector of two European countries - Italy and Spain - revealed in both countries the absence of input additionality for regional innovation funding in contrast to its presence at the national level. With regard to Italy the authors discovered significant positive impact of government support (both at regional and national levels) on process innovations, but negative impact on product innovation financing at the regional level. Researchers believe that obtained results can be explained by the fact that regional support stimulates more the "deepening" of the innovation activity rather than the production of new products. In addition, a negative relationship between regional funding and improvement of employees' qualification could be identified in case of the Italian companies. Also the same consistent pattern was found for networking with other companies aimed at obtaining information, while in the case of information networking with the scientific organizations the effect of regional funding has been, in contrast, positive.

In the study of Montmartin, Herrera (2015) devoted to the analysis of the public financial support and tax incentives on the scale of private funding of R\&D on the basis of data for 25 OECD countries over a twenty-year period (1990-2009), the authors came to the conclusion that tax incentives at the country level increase the intensity of business expenditure on $\mathrm{R} \& \mathrm{D}$, while direct government funding leads rather to the opposite result. In a more "localized" study (Montmartin et al. 2015) on the basis of data from 94 regions of mainland France for 2001-2011, the authors analyzed the direct and indirect impact of financial support provided at the regional, national and supranational (EU) level on private R\&D spending. The results suggest that a significant input additionality

Figure 2 -Additionality of direct financial support for innovation activities of companies - generalization of empirical evidence

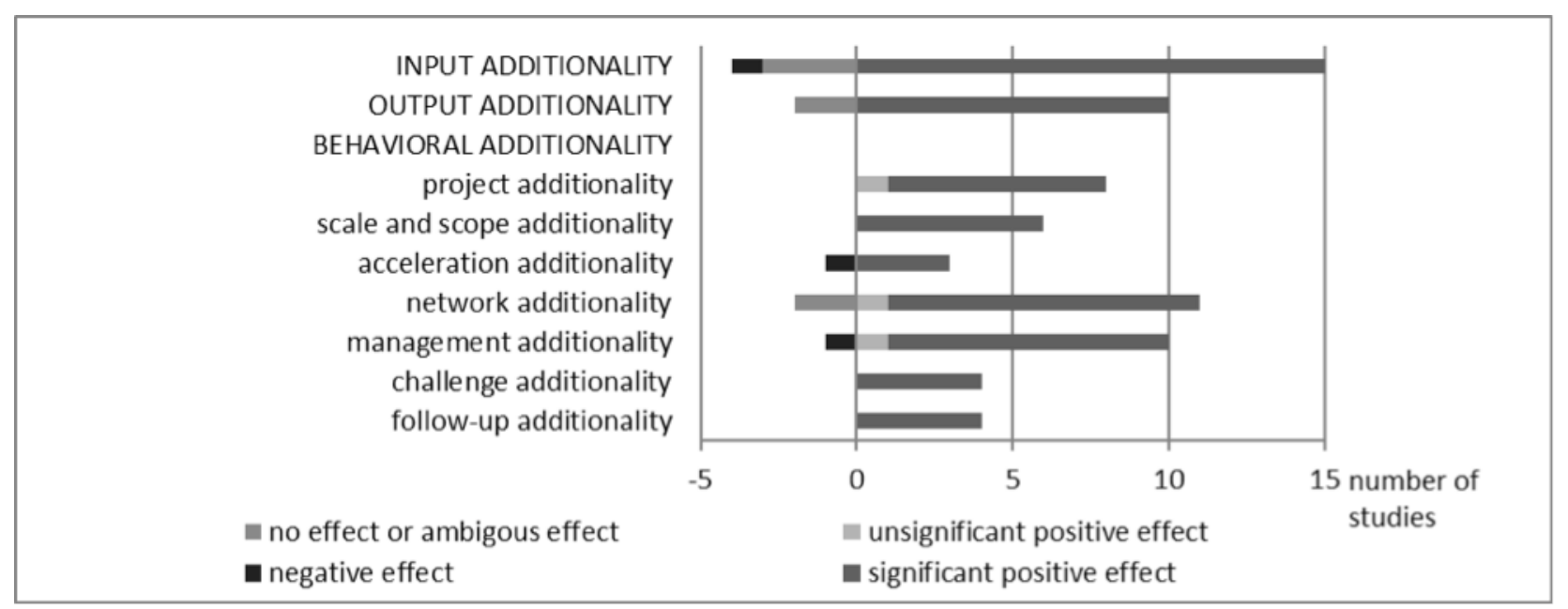

Sources: based on Đallejón, Quevedo (2005), Pegler (2005), Georghiou et al. (2005), OECD (2006), González et al. (2005), Czarnitzki, Licht (2006), Fier et al. (2006), Falk (2007), Busom. Ribas (2008), Hsu et al. (2009), Gelabert et al. (2009), Clausen (2009), Knockaert, Spithoven (2009), Idea Consult (2009), Baghana (2010), Wanzenbock et al. (2011), Catozzella, Vivarelli (2011), Marzucci, Montresor (2012), Antonioli et al. (2012), Lucena, Afcha (2013), Lohmann (2014), Hud, Hussinger (2014), Montmartin, Herrera (2015), Cantner, Kösters (2015), Montmartin et al. (2015). 
was revealed only for the national government subsidies, while the corresponding additionality was statistically insignificant for EU financing and regional subsidies.

Quite interesting and unexpected results have been received by Lohmann (2014) through in-depth interviews with project managers in the airline industry: government participation in financing of projects, contrary to expectations, did not lead to the reduction in terms of their implementation time, but on the contrary - to prolongation, meaning that the acceleration additionality is negative. This is determined by the long period of provision of subsidies which significantly exceeded the typical duration of supported projects. At the same time, however, a number of respondents described the increase in duration as a result of public support for projects as a positive effect, which allowed carrying out more detailed projects and thus increasing the chances of their successful implementation.

Tax incentives are considerably less the object of additionality studies. As a rule, researchers only considered the input additionality and obtained an empirical evidence of its presence (Figure 3). In the above mentioned research (Montmartin et al. 2015), the authors came to the conclusion that the direct positive effect of tax incentives for a particular region approximately balances the indirect negative effect for the other regions.

Figure 3 - Additionality of tax incentives for innovation activities of companies - generalization of empirical evidence

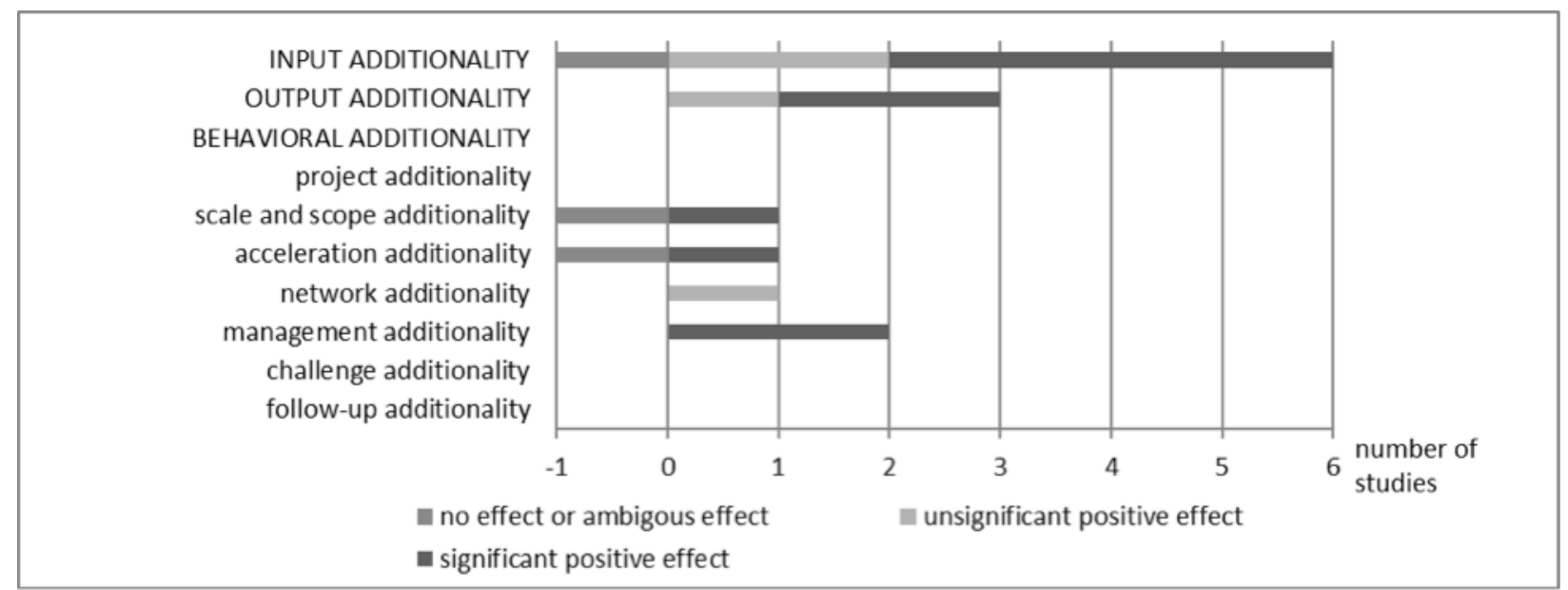

Sources: based on Poot et al. (2003), Hægeland, Møen (2007), Catozzella, Vivarelli (2011), Lokshin, Mohnen (2012), Zoran, Botrï (2013), Neicu et al. (2014), Montmartin, Herrera (2015), Freitas et al. (2015), Montmartin et al. (2015).

\section{OBJECTIVES, METHOD AND DATA}

The aim of our study is to perform a microeconomic evaluation of support provided to industrial firms in Russia by focusing on two main instruments: direct funding and tax incentives. The usage of these two instruments for the analysis is quite straightforward as they are traditionally viewed as key elements of the national innovation policy toolbox (e.g. David et al. (2000); OECD (2015)) and are well ahead of other instruments in terms of "coverage" and number of firms supported (Kuzyk, Simachev 2013).

The objectives of this study were as follows:

- firstly, to identify the "typical profile" of the firms-beneficiaries of the government support policy as a whole and of direct funding and tax incentives in particular;

- secondly, to consider basic input, output and behavioral additionality effects;

- thirdly, to analyze the "relative" additionality of direct financial support and tax incentives.
- Data were collected from a questionnaire-based survey, which addressed top executives of Russian manufacturing firms in September-October 2015.

The organizer of the survey was the Interdepartmental Analytical Center. The field operation was carried out by the publishing and information center "Statistics of Russia". While constructing the sample we targeted public support recipients to meet the research objectives. Thereby we tried to capture in our sample, on the one hand, mostly high technology industries which are relatively more often supported by the government in Russia than low-tech and medium-tech industries (Zudin 2015) and, on the other, large companies because as results of several studies prove they become more often beneficiaries of government support more in comparison with SMEs (Fier, Heneric 2005; Aschhoff 2010; Simachev et al. 2014a). As a result, the final sample consisted of 658 firms, $3 / 4$ of which belong to high-tech industries - first of all from the chemical and machine-building complex. The sample is characterized by an equal share of small companies and relatively large enterprises (while the general population is dominated by small firms) (Table. 1). Additionally, it should be noted that in the sample - as in the whole of Russian industry - companies with private ownership prevail, but at the 
same time public companies are also widely represented, what is very important from the standpoint of public support distribution analysis and its results. Finally, a major part of the surveyed firms are in a relatively healthy financial condition, but companies experiencing financial problems are also significantly represented in the sample.

Table 1. Sample structure

\begin{tabular}{|c|c|c|}
\hline Characteristic & & $\begin{array}{l}\text { Share in the } \\
\text { sample }\end{array}$ \\
\hline \multirow[t]{15}{*}{ Industry } & Manufacturing textiles, clothing and footwear & $7,45 \%$ \\
\hline & Wood processing, manufacturing of wood products, pulp, paper and paperboard & $5,32 \%$ \\
\hline & Chemical production (excluding pharmaceutics) & $6,23 \%$ \\
\hline & Manufacturing of pharmaceutical products & $4,71 \%$ \\
\hline & Metallurgy, manufacturing of finished metal products & $9,73 \%$ \\
\hline & Manufacturing of machinery and equipment (except for machine-tools) & $18,84 \%$ \\
\hline & Manufacturing of machine-tools & $3,95 \%$ \\
\hline & Manufacturing of electrical machinery and electrical equipment & $8,36 \%$ \\
\hline & $\begin{array}{l}\text { Manufacturing of computer technology, equipment for processing } \\
\text { information, radio, TV and telecommunication }\end{array}$ & $9,42 \%$ \\
\hline & Manufacturing of medical equipment & $4,86 \%$ \\
\hline & Manufacturing of control and measuring devices & $3,65 \%$ \\
\hline & Automobile production & $4,56 \%$ \\
\hline & Shipbuilding & $4,10 \%$ \\
\hline & Manufacturing of railway rolling stock & $4,86 \%$ \\
\hline & Manufacturing of aircraft & $3,95 \%$ \\
\hline \multirow[t]{4}{*}{ Operation period } & less than 5 years & $8,81 \%$ \\
\hline & $5-10$ years & $16,26 \%$ \\
\hline & $10-20$ years & $26,90 \%$ \\
\hline & more than 20 years & $48,02 \%$ \\
\hline \multirow[t]{3}{*}{ Ownership } & state and municipal (including the ownership of state-owned corporations) & $9,27 \%$ \\
\hline & mixed & $5,78 \%$ \\
\hline & private & $84,95 \%$ \\
\hline \multirow[t]{4}{*}{ Number of employees } & less than 100 emp. & $24,77 \%$ \\
\hline & 101-200 emp.. & $22,95 \%$ \\
\hline & 201-500 emp.. & $24,32 \%$ \\
\hline & more than 500 emp.. & $27,96 \%$ \\
\hline \multirow[t]{3}{*}{ Financial condition } & poor & $17,93 \%$ \\
\hline & satisfactory & $69,91 \%$ \\
\hline & good & $12,16 \%$ \\
\hline
\end{tabular}

Sources: prepared by the authors 
To determine the composition of the companies that are "consumers" of government support we used a questionnaire in which respondents were asked to mark if they had received budget financing, used tax incentives or other public support instruments and measures in 20132015. Actually, the analysis of the public support results and additionality is based on the responses from CEOs for covering a wide range of corresponding effects related to "classical" types of additionality with the exception of management and follow-up additionality (Table 2). It is important to note that one of the main restrictions of the survey was that we only asked one person in a company. CEOs were chosen as they are actually better informed compared to any other single specialist regarding the firm's profile, its position on the market and most importantly the impact of public support of different kinds on its activities and organizational routines.

Table 2. Comparison of the public support effects and different types of additionality

\begin{tabular}{|c|c|}
\hline Effect & Additionality \\
\hline $\begin{array}{l}\text { volume of company's investment in new equipment } \\
\text { based on its own or borrowed funds has increased }\end{array}$ & \multirow{3}{*}{ input } \\
\hline $\begin{array}{l}\text { volume of company's spending on innovation } \\
\text { based on its own or borrowed funds has increased }\end{array}$ & \\
\hline $\begin{array}{l}\text { volume of company's spending on R\&D based } \\
\text { on its own or borrowed funds has increased }\end{array}$ & \\
\hline company's revenue has increased & \multirow{6}{*}{ output } \\
\hline $\begin{array}{l}\text { company's market share on the } \\
\text { domestic market has increased }\end{array}$ & \\
\hline $\begin{array}{l}\text { company's market share on the } \\
\text { external market has increased }\end{array}$ & \\
\hline $\begin{array}{l}\text { production volume of new (improved) } \\
\text { products has increased }\end{array}$ & \\
\hline $\begin{array}{l}\text { profitability of core company's } \\
\text { activities has improved }\end{array}$ & \\
\hline company's general competitiveness has increased & \\
\hline $\begin{array}{l}\text { import dependence of the company } \\
\text { has been reduced }\end{array}$ & import substitution \\
\hline a promising new project (projects) was launched & project \\
\hline $\begin{array}{l}\text { public support has allowed to implement } \\
\text { a larger project (projects) }\end{array}$ & \multirow{2}{*}{ scale and scope } \\
\hline $\begin{array}{l}\text { public support has allowed to implement a } \\
\text { project (projects) with a longer payback period }\end{array}$ & \\
\hline $\begin{array}{l}\text { public support accelerated the } \\
\text { implementation of the project }\end{array}$ & acceleration \\
\hline $\begin{array}{l}\text { public support reduced risks of } \\
\text { project implementation }\end{array}$ & challenge \\
\hline $\begin{array}{l}\text { development (strengthening) of the } \\
\text { company's linkages within scientific and } \\
\text { industrial cooperation has occurred }\end{array}$ & network \\
\hline $\begin{array}{l}\text { public support has allowed to redistribute } \\
\text { part of company's funds towards the other } \\
\text { areas not related to the subject of support }\end{array}$ & - \\
\hline
\end{tabular}

Sources: prepared by the authors
We associate the reduction of risks of innovation activities as a result of public support with the 'challenge additionality' since this effect contributes to the risk "tolerance" of companies and thus to the initiation and implementation of more risky projects. Reducing import dependence of companies (an item which was included in the scope of the analysis due to the active implementation of the import substitution policy in the Russian industry) does not directly correspond to any of the "classic" types of additionality and for this reason we regard it as a separate category. Finally, the redistribution of existing funds towards other areas not related to the subject of public support is nothing more than the well-known and frequently observed "crowding out" effect in national and foreign studies, which is the opposite to input additionality (David et al. 2000; Lach 2002; Chudnovsky et al. 2006; Benavente et al. 2007; Simachev et al. 2015).

We use frequency and regression analysis to identify the specifics of the beneficiaries of public support and reveal its main additionality effects. For a more precise definition of "relative" additionality effects of direct funding and tax incentives we used a propensity score matching (PSM) which is one of the main techniques of analyzing additionality at firm level (e.g. Fier et al. (2006); Baghana (2010); Marzucchi, Montresor (2013); Cantner, Kösters (2015)). An important distinguishing feature of our approach is that we analyzed the additionality of a concrete instrument for a particular firm relative to all other instruments used and therefore could consider the "relative" additionality. This enables us to highlight inherent additionality effects precisely to tax and financial instruments distinguishing them from the "background" of all other elements of the innovation policy toolbox.

It is necessary to pay attention to two important limitations of our study. Firstly, we analyzed the "generalized" streams of public support (direct financial support and tax incentives). More specifically, in our research we did not focus on particular instruments but considered financial support and tax incentives in any form. It seems to us justifiable because these two policies are fundamentally different and companies tend to choose a set of instruments of one kind - financial or tax (Ivanov et al. 2012). Note also that such a "generalized" approach is widely used in modern empirical studies (e.g. Gelabert et al. (2009); Lokshin, Mohnen (2012); Marzucci, Montresor (2012); Hud, Hussinger (2014); Bodas Freitas et al. (2015)).

Secondly, we do not distinguish between federal and regional support. Meanwhile, as noted above, the effects of such support can vary considerably (Marzucchi, Montresor 2013). However, such differences most clearly manifest themselves in the case of financial support. In Russia the financing of innovation activities from the federal budget significantly exceeds the volume of the relevant funding at the regional and local levels (Gorodnikova et al. 2016).

\section{RESULTS}

\section{BENEFICIARIES OF PUBLIC SUPPORT - THE TYPICAL PROFILE}

Before analyzing additionality results caused by tax and financial instruments we briefly turn to the formation of the typical profile of the beneficiaries of public support. On the whole one third of the sampled companies used some public support instruments in 2013-15; while 20 per cent of companies have received government funding, about the 
same - 21 per cent have made use of different tax incentives and 10 per cent of companies received both streams of support.

Large and long operating (over 20 years) companies have more frequently become the recipients of public support than relatively newly established and small (100-200 employees) companies. Note that such a "failure" of the public support in relation to small firms was observed by us earlier (Simachev et al. 2014a).

Figure 4 - Receiving state support in 2013-2015 by companies of different categories - percentage of the total company sample by category

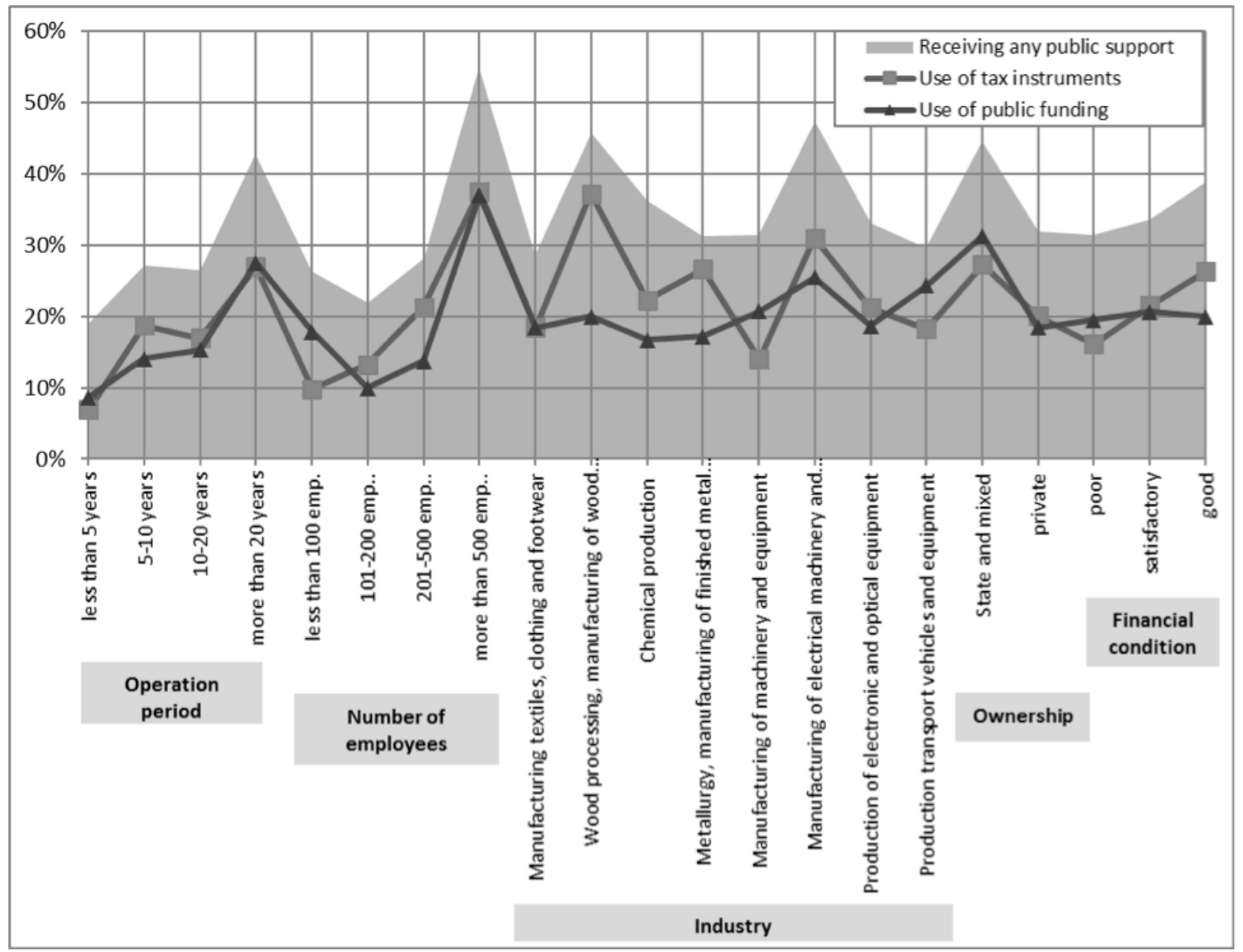

Sources: prepared by the authors

When considering different industries one can note a certain "concentration" of both public support dimensions in the field of electrical equipment production and also a relatively frequent use of tax incentives by wood processing companies in a line with pulp and paper industry companies. Finally, companies with government participation in capital more frequently become the beneficiaries of financial support and tax incentives.

Regression analysis by including the explanatory variables presented in Figure 4 allows us to define more clearly the profile of beneficiaries using different tax and financial support instruments (Table 3.) The use of tax incentives in the review period was most typical for large companies and unusual for SMEs (not more than 200 employees). Large and long-operating companies had the greatest chance to receive government financial support; at the same time, however, small firms also often became the recipients of budget funds. 
Table 3. State support for companies in 2013-15 - results of the binary logistic regression model

\begin{tabular}{|c|c|c|c|c|}
\hline \multirow{2}{*}{\multicolumn{2}{|c|}{ Independent variables (dummy) }} & \multicolumn{3}{|c|}{ Dependent variables (dummy) } \\
\hline & & $\begin{array}{l}\text { Receiving any public } \\
\text { support }\end{array}$ & Use of tax instruments & Use of public funding \\
\hline \multirow{8}{*}{ Industry } & Manufacturing textiles, clothing and footwear & \multicolumn{3}{|c|}{ control } \\
\hline & $\begin{array}{l}\text { Wood processing, manufacturing of wood } \\
\text { products, pulp, paper and paperboard }\end{array}$ & $+^{*}$ & $+^{* *}$ & \\
\hline & Chemical production & & & \\
\hline & Metallurgy, manufacturing of finished metal products & & & \\
\hline & Manufacturing of machinery and equipment & & & \\
\hline & $\begin{array}{l}\text { Manufacturing of electrical machinery } \\
\text { and electrical equipment }\end{array}$ & $+^{*}$ & & \\
\hline & Production of electronic and optical equipment & & & \\
\hline & Production transport vehicles and equipment & & & \\
\hline \multirow{4}{*}{ Operation period } & less than 5 years & & & \\
\hline & $5-10$ years & & & \\
\hline & $10-20$ years & \multicolumn{3}{|c|}{ control } \\
\hline & more than 20 years & $+^{* *}$ & & $+^{* *}$ \\
\hline \multirow{2}{*}{ Ownership } & State and mixed & & & \\
\hline & private & \multicolumn{3}{|c|}{ control } \\
\hline \multirow{4}{*}{ Number of employees } & less than 100 emp. & & $-* *$ & $+^{*}$ \\
\hline & 101-200 emp.. & & $-{ }^{*}$ & \\
\hline & 201-500 emp.. & \multicolumn{3}{|c|}{ control } \\
\hline & more than 500 emp.. & $+^{* * *}$ & $+^{* *}$ & $+^{* * *}$ \\
\hline \multirow{4}{*}{ Financial condition } & poor & & & \\
\hline & satisfactory & \multicolumn{3}{|c|}{ control } \\
\hline & good & & & \\
\hline & Chi-square & $78,39^{* * *}$ & $66,98^{* * *}$ & $65,44^{* * *}$ \\
\hline & N & \multicolumn{3}{|c|}{658} \\
\hline
\end{tabular}

Notes:

Maximum VIF value - 3,20.

* $\quad$ - significant a $10 \%$ level;

* - significant a $5 \%$ level;

*** - significant a $1 \%$ level.

Sources: prepared by the authors

Interestingly, the regression analysis revealed no statistically significant relationship between private industrial companies and fully public companies or companies with mixed ownership, which is consistent with previous empirical results (Simachev et al. 2014a).

\section{MAIN EFFECTS OF PUBLIC SUPPORT}

Talking about input additionality the most widely observed effect is the increase in investment in new equipment based on own or borrowed funds. Interestingly, almost as often respondents mentioned the crowding out effect (see Table 4.).

The most common output effects of public support are the increase of new and improved products produced and increases in revenue, as well as growth of profitability and general company competitiveness. In contrast, least likely public support led to increasing market shares of companies on the external markets. Although not significantly, public policies of any kind also contributed to a decreasing import dependence 
of the scrutinized companies. Among the key behavioral effects of public support one can find accelerated project implementation and encouragement of launching new projects. Government support relatively rarely led to the development of scientific-industrial cooperation, which seems very surprising in view of the impressive scale of the public policy in recent years aimed at encouraging network between science and industry (Simachev, Kuzyk 2015).

Input, output, as well as behavioral additionality was effected to a significantly greater extent by financial instruments than by tax incen- tives (Table 4). Financial support significantly stood out from the other instruments in terms of effects such as growth of investment in new equipment, increase in production volumes of new and improved products, acceleration of project implementation and risk tolerance At the same time, the crowding-out of own private funds through government funds was higher in case of direct financial support.

Table 4. Major results of public support - frequency statistics

\begin{tabular}{|c|c|c|c|}
\hline & $\begin{array}{l}\text { All the recipients of } \\
\text { government support }\end{array}$ & $\begin{array}{l}\text { Companies using tax } \\
\text { incentives }\end{array}$ & $\begin{array}{l}\text { Companies enjoying } \\
\text { public funding }\end{array}$ \\
\hline INPUT ADDITIONALITY & $35,6 \%$ & $36,7 \%$ & $42,5 \%{ }^{*}$ \\
\hline $\begin{array}{l}\text { - volume of company's investment in new equipment based } \\
\text { on own or borrowed funds has increased }\end{array}$ & $28,4 \%$ & $25,9 \%$ & $34,3 \%^{* *}$ \\
\hline - volume of company's spending on innovation based on own or borrowed funds has increased & $15,3 \%$ & $17,3 \%$ & $17,2 \%$ \\
\hline - volume of company's spending on R\&D based on own or borrowed funds has increased & $15,8 \%$ & $17,3 \%$ & $18,7 \%$ \\
\hline OUTPUT ADDITIONALITY & $47,3 \%$ & $48,2 \%$ & $56,0 \% * * *$ \\
\hline - company's revenue has increased & $18,9 \%$ & $16,5 \%$ & $20,9 \%$ \\
\hline - company's market share on the domestic market has increased & $13,5 \%$ & $10,1 \%{ }^{*}$ & $16,4 \%$ \\
\hline - company's market share on the external market has increased & $2,7 \%$ & $2,9 \%$ & $2,2 \%$ \\
\hline - production volume of new (improved) products has increased & $21,2 \%$ & $19,4 \%$ & $27,6 \% * * *$ \\
\hline - profitability of core company's activities has improved & $18,0 \%$ & $18,0 \%$ & $17,9 \%$ \\
\hline - company's general competitiveness has increased & $18,9 \%$ & $16,5 \%$ & $22,4 \%$ \\
\hline $\begin{array}{l}\text { IMPORT SUBSTITUTION ADDITIONALITY } \\
\text { - import dependence of the company has been reduced }\end{array}$ & $4,1 \%$ & $4,3 \%$ & $4,5 \%$ \\
\hline BEHAVIORAL ADDITIONALITY & $44,6 \%$ & $46,0 \%$ & $55,2 \% * * *$ \\
\hline - a promising new project (projects) was launched & $19,8 \%$ & $21,6 \%$ & $24,6 \%{ }^{* *}$ \\
\hline - public support has allowed to implement a larger project (projects) & $11,7 \%$ & $12,9 \%$ & $14,2 \%$ \\
\hline - public support has allowed to implement (projects) with a longer payback period & $12,6 \%$ & $15,1 \%$ & $14,2 \%$ \\
\hline - public support accelerated implementation of the project & $21,6 \%$ & $20,9 \%$ & $26,9 \% * *$ \\
\hline - public support enabled to reduce risks of project implementation & $13,5 \%$ & $15,1 \%$ & $17,2 \%^{*}$ \\
\hline $\begin{array}{l}\text { - development (strengthening) of the company's linkages within } \\
\text { the scientific and industrial cooperation has occurred }\end{array}$ & $8,1 \%$ & $8,6 \%$ & $9,7 \%$ \\
\hline $\begin{array}{l}\text { CROWDING-OUT EFFECT } \\
\text { - public support has allowed to redistribute part of company's funds towards other areas not } \\
\text { related to the subject of support }\end{array}$ & $29,3 \%$ & $27,3 \%$ & $37,3 \% * * *$ \\
\hline N & 222 & 139 & 134 \\
\hline
\end{tabular}

Notes:

The significance of differences, the Chi-square test

* - significant a $10 \%$ level;

** - significant a $5 \%$ level;

*** - significant a $1 \%$ level.

Sources: prepared by the authors 


\section{RELATIVE ADDITIONALITY OF TAX INCENTIVES AND PUBLIC FUNDING}

In this section we would address the "relative" additionality, i.e. the additionality of a concrete instrument for a particular firm relative to all other used instruments, to capture "net" additionality effects.

For a more precise identification and comparison of the effects generated by tax respectively financial support, we use the following typical algorithm²:

1. The first step involved the assessment of the two sets of expected probabilities (propensity scores) of using tax incentives or of obtaining financial support by building bivariate logistic regressions with a "standard" set of control variables for the sampled companies (see Table 3). Since the questionnaire about public support effects was addressed only to recipients evaluation was carried out under the sub-sample of companies which obtained government support of any form in 2012-15.

2. Secondly, for the analyzed two dimensions of public policy (tax incentives and direct financial support), pairs of most similar recipients and non-recipients were identified. Pairs were formed by nearest neighbor matching on the basis of propensity score variables created at the first step

3. Thirdly, the average effects on the treated companies (or ATTs) for tax and financial support were estimated (for more details see Newey (2009)). It is important to note that initially this effect is described by the following functional dependence

$$
A T T_{i j}=E\left(Y_{i j}^{1}-Y_{i j}^{0} \| S_{i}=1\right)=E\left(Y_{i j}^{1} \| S_{i}=1\right)-E\left(Y_{i j}^{0} \| S_{i}=1\right) \quad(1)
$$

где i - considered dimension of support (tax or financial); j - specific effect of the support; $Y_{i j}^{1}$ - indicator of presence or absence of the effect in case of receiving support of $j$ type $i ; Y_{i j}^{0}$ - the corresponding indicator in the hypothetical situation, if this type of support has not been received; $\mathrm{Si}$ - indicator of obtaining support of a specific type i 1 - presence, 0 -absence).

The main problem here is that the indicator is unobservable, so it is necessary for the calculation to find an approximation. Steps 1 and 2 enabled us to do this by using the observed values of this indicator obtained for the "most similar" companies, which were not recipients of a specific support type. As a result, the functional dependence takes the following form:

$$
A T T_{i j}=E\left(Y_{i j}^{1} \| S_{i}=1\right) \square E\left(Y_{i j}^{0} \| S_{i}=0\right)
$$

Note that since the variables and are binary, the mean of ATTS are located in the range from - 1 to 1 . The ATT's zero value corresponds to the case where the average values of indicators $\quad Y_{i j}^{1} \| S_{i}=1$ and $Y_{i j}^{0} \| S_{i}=0$ (or the value of effect for recipient and non-recipient consequently) is identical. This means that the use of the specific instrument does not increase or reduce the likelihood of a certain effect compared with the total set of public incentive mechanisms. Thus, the ATT indicator in this case reflects the "relative" additionality, provided by a certain dimension (tax or financial) on the background of general public support policy.

Evaluation results indicate that across almost all considered effects the impact of financial measures exceeds the impact of tax incentives. Exceptions are only two output indicators (the market share on the external market and profitability) and the scale and scope additionality (Figure 5).

Figure $\mathbf{5}$ - Relative additionality of tax and financial support - average treatment effects on the treated sub-sample of companies which received government support in 2013-15

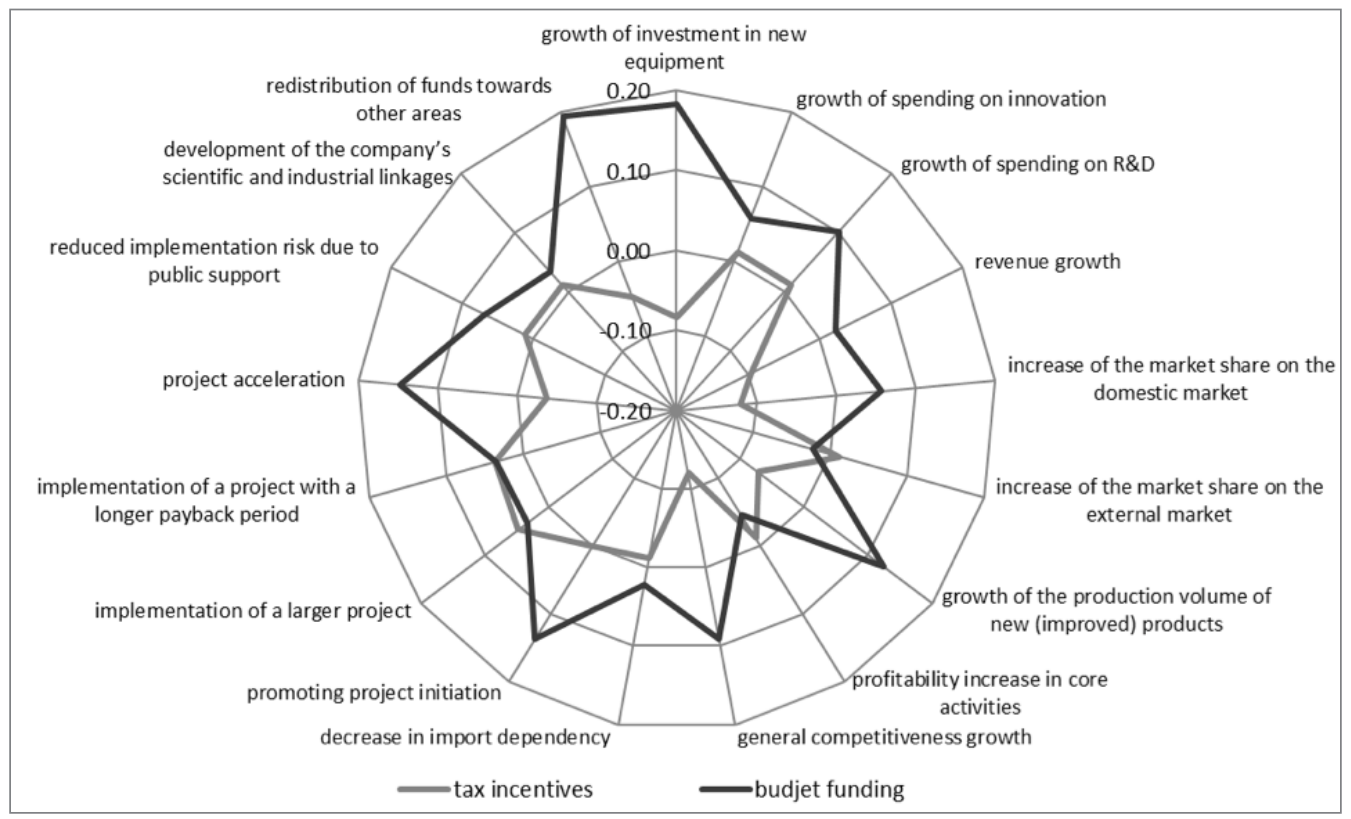

Sources: prepared by the authors 
The most significant "failure" of the tax instruments' impact is observed in respect of the investments in new equipment, the market share on the domestic market and the general competitiveness of the company. At the same time, it is important to note that the crowding out effect is inherent to a much greater extent to financial instruments than to tax measures.

Aggregation of ATT values for input, output and behavioral additionality revealed that financial support most strongly affects the input company characteristics with a noticeable positive impact also on its output and behavioral parameters (Figure 6). In comparison tax measures have lower additionality effects, especially in terms of output additionality.

We take now a brief look at the question how company characteristics relate to specific effects. We calculated the parameters of ordinal regression models in which the dependent variables were the individual treatment effects on the treated companies ${ }^{3}$ - the differences between the effects (with values 1 or 0 ) in the "recipient non-recipient" pairs: - .
Explanatory variables reflect all of the above "standard" characteristics of companies (Table 3), except for the industry sector which was not sufficiently representative in the sub-sample formed by pairs of recipients and non-recipients of tax and financial support. For this reason, the industries have been aggregated according to their technology level${ }^{4}$. In these models values of control variables correspond to those of the recipients (treated). Below only results for the meaningful models are presented (Table 5).

The results though should be interpreted with great caution due to the relatively small number of observations (pairs of "recipient / non-recipient"). Nevertheless, we believe it is important to note two consistent patterns (at least as a hypothesis for further empirical testing on larger samples): first, the effects of tax support occur more often in companies with state or mixed ownership and, second, the positive impact of tax incentives is less typical for small businesses than for larger firms.

Figure 6 - Relative input, output and behavioral additionality of tax and financial support measures - average effects on the treated (ATT) sub-sample of companies which received government support in 2013-15

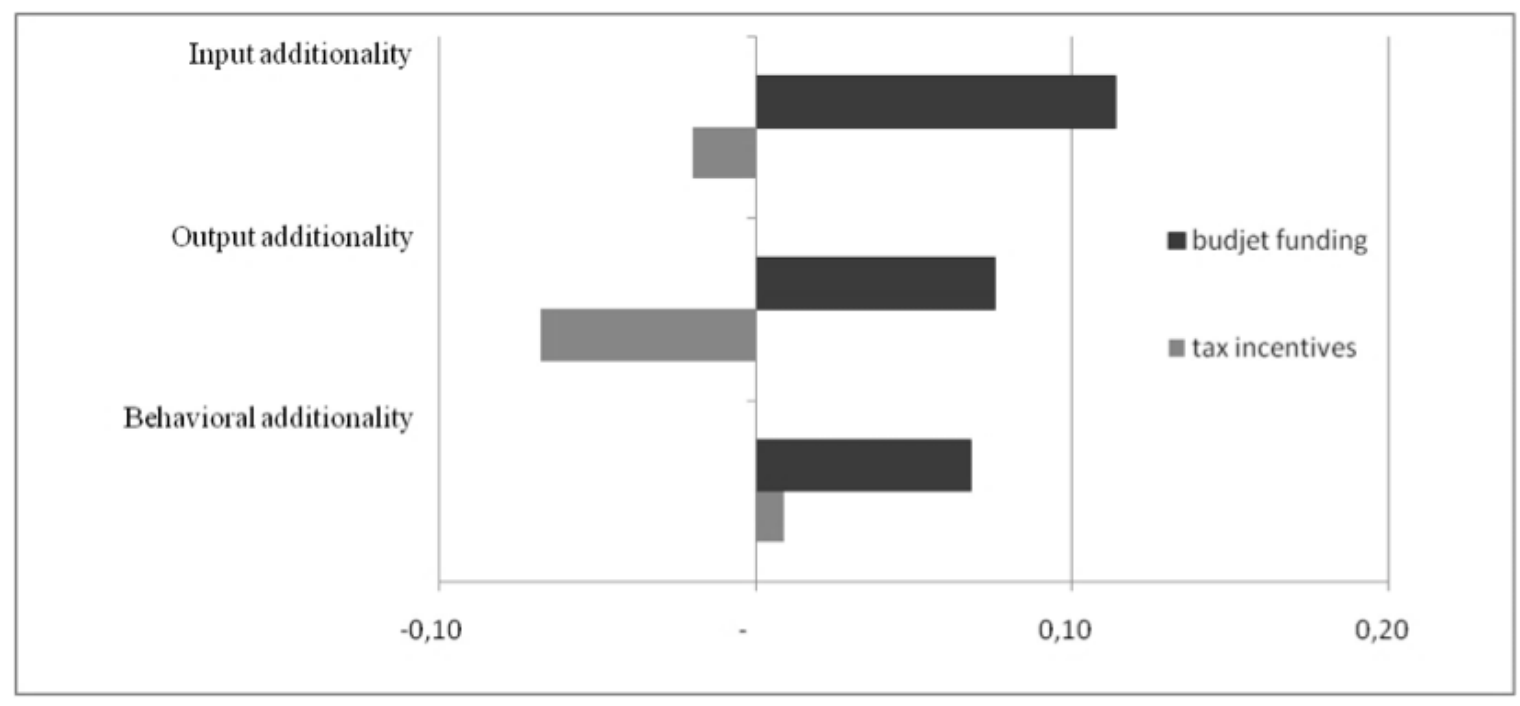

Sources: prepared by the authors

3 This approach is used, in particular, in Hottenrott, Lopes-Bento (2013).

$4 \quad$ In our sample the low-tech industries include textiles, clothing and footwear, wood processing and pulp and paper industry, medium-tech includes metals and fabricated metal products, high-tech includes chemical industry and mechanical engineering (for more details see Zudin (2015)). 
Table 5. Individual treatment effects on the treated for tax and funding instruments - calculation results of the binary logistic regression model

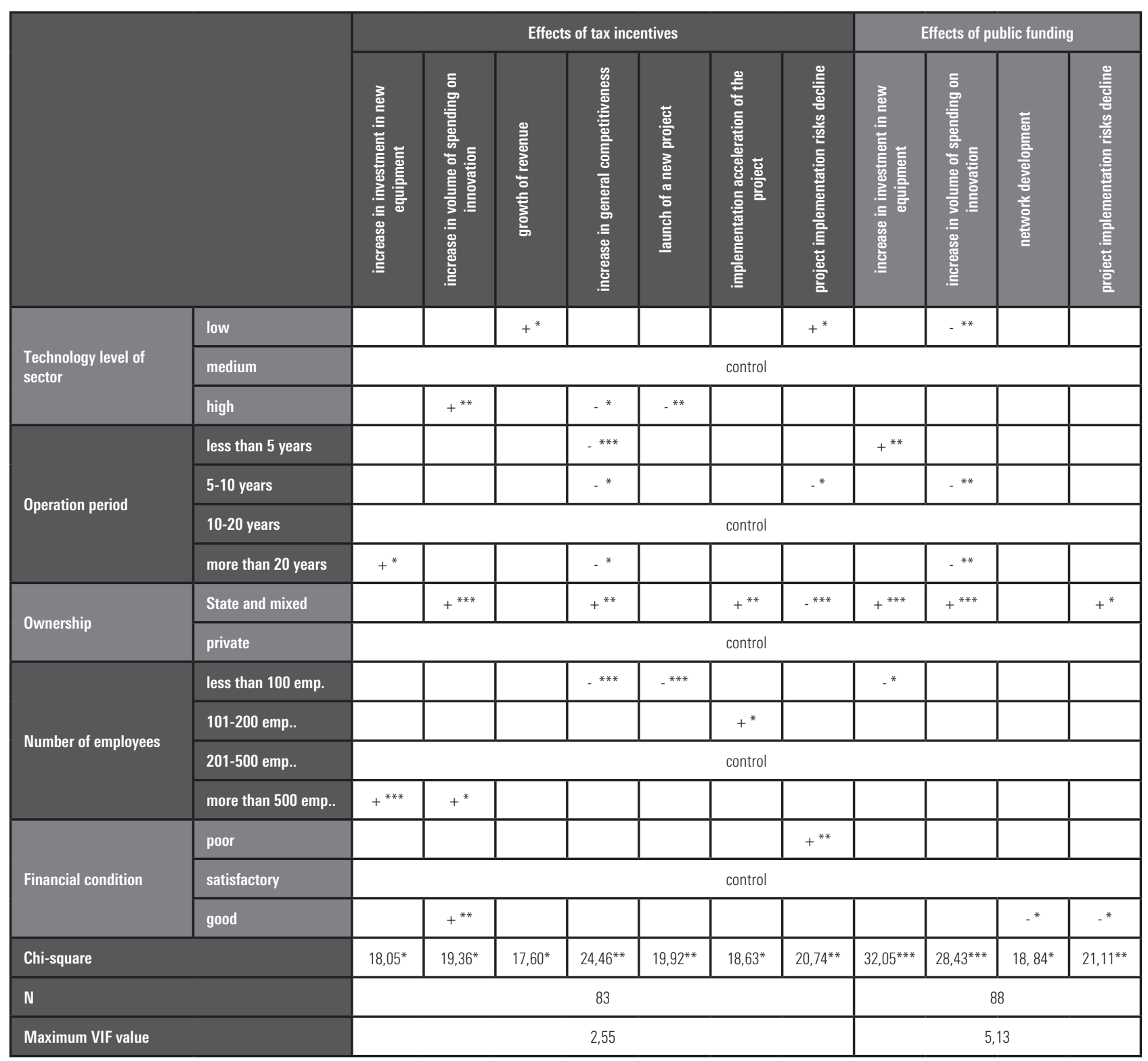

Notes:

* - significant a $10 \%$ level;

** - significant a $5 \%$ level;

*** - significant a $1 \%$ level.

Sources: prepared by the authors 


\section{DISCUSSION AND POLICY IMPLICATIONS}

1. The ongoing Russian public policy to stimulate firms' development through a substantial variety of instruments for different target groups (e.g. Kuzyk, Simachev (2013) $)^{5}$ is characterized by a strong emphasis on sufficiently large and long-operating companies. Such a result is not surprising, especially not for the Russian economy. Positive relationship between the size of the firms and the likelihood of receiving government support has been identified in a number of empirical studies (e.g. Fier, Heneric (2005); Aschhoff (2010); Simachev et al. (2014a)).

The focus shift of public support towards large and long operating companies occurs due to a number of factors. Firstly, these companies are more "visible" for the state and objectively are better able to lobby their interests in the government. Secondly, a large established business has a strong and highly diversified system of connections with the public authorities and a lot of experience in attracting and using government support. The latter is particularly important because, as has been shown in several studies, the company which has previously received support is more likely to receive it in the future too ${ }^{6}$ (e.g. Falk (2006); Aschhoff (2009)). Thirdly, as it is noted in the study of Garcia and Monhen (2010), a greater proportion of large companies in the set of public support recipients may indicate a risk aversion of the government: indeed, support of a relatively small number of large companies in comparison with a lot of smaller firms is associated with lower transactional costs of support allocation and administration. Moreover, because large companies often demonstrate a "formally" higher innovation activity authorities tend to support them to generate a pseudo-positive result important for reporting (Simachev et al. 2014a). Finally, especially in periods of crisis, the government is more inclined to support large companies across particular industries, regions or/and the national economy as a whole ${ }^{7}$ (Simachev et al. 2010).

The question on the relative efficiency of government support for small and large firms is rather controversial. Today one can find empirical evidence of significant influence of government support both on SMEs, including behavioral changes (Loof, Heshmati 2005; Wanzenbock et al. 2013), as well as substantial corresponding changes in large firms (Falk 2006). The obtained results of our study rather confirm the second point of view. However, due to the relatively small number of relevant observations, we can only hypothesize that in Russia instruments of government support (especially tax incentives) provide positive changes mainly for medium and large sized firms.

Our view is that "quality" of the recipients and not formal characteristics of beneficiaries (such as size, age etc.) should matter and qualify for government support. The recipients of government support should have a big potential for further successful development and, what is more important, demonstrate abilities to implement it. However, in Russian reali- ties that principle is not always followed. In periods of relative economic stability the government mostly supports successfully developing firms (e.g. Simachev et al. (2014a)), whereas crises force the government to shift the support focus towards troubled companies, especially if these are of a great importance in the context of providing socio-economic stability in the region or/and in the whole country (Higher School of Economics, Interdepartmental Analytical Center 2009; Mau 2010).

2. Tax and financial instruments of government support have de facto different target audiences: the use of tax incentives is not likely for small firms, whereas medium-sized companies relatively rarely appear to be recipients of financial support. The former can be the reflection of both the imperfect parameters of the tax instruments (their rate, base, etc.) for small businesses and the existence of significant implementation and administration problems, which are acceptable for large companies but too excessive for small firms. The fact of relatively rare financial support of medium-sized firms can be considered as another empirical evidence of a lack of instruments aimed at funding medium-sized projects and companies. (see also Simachev et al. (2012)).

3. The relatively small impact of government support on sciencebusiness cooperation seems to us quite unexpected labroad, this effect is among the most frequently observed ones, especially in the case of financial support - e.g. Pegler (2005); Busom, Fernandez Ribas (2008); Idea Consult (2009); Marzucchi, Montresor (2013)). This fact is rather discouraging, as the Russian government makes considerable effort to enhance linkages and interactions between the R\&D sector and industry. In the last few years, the government initiated a number of policies fully or to a large extent focused on the development of cooperation: financial support for projects to develop high-tech industries, executed by companies in cooperation with universities and research institutions; creation of a technological platform network; approval and implementation by the largest public sector companies of the medium-term innovative development programs which include cooperation activities with universities and research institutions; promotion of support programs for the development of innovative territorial clusters etc. The absence of an explicit result of these efforts, to our mind, can be explained by the fact that government support often does not lead to the creation of new linkages and partnerships but only contributes to the "capitalization" of long-established ones (Simachev et al. 2014c). It is worthwhile to note that a significant contribution of government support to the improvement of existing science-business linkages and partnerships has been widely observed abroad (e.g. Georghiou et al. (2005); Lohmann (2014)).

4. Our empirical analysis as well as a significant number of earlier studies confirmed the importance of the financial support in providing all major aspects of additionality. Based on our results, we can say that in Russia the effects of the financial instruments cover all three main types of additionality. The main input effect is the increase of investment in new equipment; the main output effect is the increase of production of new and improved products, and the main behavioral effect is the initiation of new perspective projects and an acceleration of project

5 Despite the fact that Russian industrial innovation policy toolbox is rather diversified

$6 \quad$ In literature this effect is commonly called the Matthew effect: this term is used in the broader context with respect to scientific recognition (Merton 1968) and in a narrow sense in relation to public support for innovation (e.g. Crespi, Antonelli (2011)).

7 It is appropriate to mention the renewal in 2015 of the practice of public guarantee support provided for strategic organizations - the largest entities that have a significant influence on the formation of GDP, employment and social stability. Previously the government has resorted to such measures in the most acute phase of the previous crisis - in 2009 (Simachev, Kuzyk 2010). 
implementation. It should be noted that project additionality (government contribution to firms' launching new projects) is one of the most frequently observed behavioral changes (e.g. Falk (2007); OECD (2006); Idea Consult (2009)). This cannot be said about acceleration additionality (when government support speeds up the course of the project) which, according to other research, occurs on a considerably smaller scale (see Figure 2).

Unlike financial instruments, tax incentives almost do not provide significant results in terms of additionality. The most considerable "failure" is observed in relation to such expected - but not realized - effects as the supposed increase in the firms' competitiveness, the supposed growing domestic market share and the supposed increase of investment in new equipment. The negative results concerning the last indicator seem quite surprising to us as a large set of tax incentives in Russia is basically intended to stimulate firms' investment activities. At the same time and in contrast to a number of foreign studies, which examined a significant impact of tax incentives on input characteristics related to innovation activity, first of all RGD expenses (e.g. Lokshin, Mohnen (2012); Bodas Freitas et al. (2015)), we cannot see tangible input additionality of such measures in Russia. Slightly noticeable additionality effect of tax instruments relate to scale and scope additionality (the growth of investment in ongoing projects and the increase of the acceptable payback period). It is worthwhile to note that the positive impact of tax support on scale and scope of ongoing projects, in contrast to initiation of the new ones, was rather often identified in economic literature (Guellec, Van Pottelsberghe 2003; Jaumotte, Pain 2005; Simachev et al. 2014b).

The identified clear dominance of financial instruments over tax incentives with regard to most additionality effects should, in our opinion, not be considered as an exhaustive evidence of the inefficiency of tax measures and even more not as a robust argument in favor of abandonment of this element within the innovation policy portfolio. Indeed, the set of tax instruments obtains a number of important advantages. Actually, they are potentially available for a wider range of recipients than direct funding instruments. Moreover, they are associated with lower implementation and administration costs (Simachev et al. 2014b), they do not involve government intervention in market mechanisms and, what is important, they are not directly linked to budget allocation processes (Gokhberg et al. 2014). It is also important that tax measures and public funding instruments have substantially different beneficiaries. Finally, tax incentives produce to a noticeably less degree crowding out effects (replacement of private funds by public ones - e.g. David et al. (2000); Jaumotte, Pain (2005)) which is confirmed by the results of our study.

This situation, in our opinion, is explained by the fact that the expected benefits from the tax breaks are taken into account by firms ex-ante - when making a decision on the initiation of projects and defining their parameters. Financial support, on the contrary, is often only a possible, but not a guaranteed option, so in the case of obtaining such support companies prefer not to increase the project funding due to already fixed project parameters and redistribute funds for other needs.

In addition, budget funds are often invested in obviously successful projects that would have been carried out without public support on the grounds of the above-noted tendency of risk aversion of public authorities motivated by the need to demonstrate high efficiency in their programs (David et al. 2000; Klette et al. 2000; Wallsten 2000; Lach 2002).
The arguments given above, however, do not mean that tax incentives do not need improvement. On the contrary, the revealed significant "gap" in the effectiveness between financial and tax support shows in our opinion that the latter is just more in need of improvement - in terms of input and output effects, which are often observed abroad (Hægeland, Møen 2007; Lokshin, Mohnen 2012; Bodas Freitas et al 2015; Montmartin, Herrera 2015), but almost cannot be traced in Russia.

However, tax incentives productivity should not be improved through its "enrichment" with features and attributes of financial mechanisms as this would eliminate the key beneficial characteristics of tax incentives, which are the availability for a wide range of companies and low costs of use and administration. Thus, the relatively recent "improvement" of a certain tax benefit (the ability to write off a given amount of R\&D expenditure) resulted in the requirement for the companies to submit to tax authorities the full research reports, which increased the application costs of this tax break and, as a consequence, led to a sharp reduction in its popularity among firms (Simachev, Kuzyk 2015).

Finally, we would like to note that our evaluation results on the influence of tax and financial policies on companies need to be interpreted with caution. Strictly speaking, no study of this kind can claim to be a universal truth. Indeed, as evidenced by the results of numerous foreign empirical studies, even very similar mechanisms of public support can lead to significantly different results in different countries and over different periods of time, and this is due not only to the differences in the "design" of support tools, but also because of their high impact heterogeneity over sectors, companies' parameters and market functioning characteristics. The observed effects vary considerably over time, and some appear only with considerable lags.

Against the background of an objectively limited value of any single empirical research it is particularly important to reflect the huge number of studies devoted to the evaluation of impact of public support on companies, a great portion of which for the last fifteen years has been based on the concept of additionality. Such studies, especially if regularly carried out on the basis of statistical data for long observation periods, often include cross-country comparisons of the results. Finally, and most important - they are in demand by the government and are implemented in the decision-making system. For Russia, surprisingly, our attempt to estimate the additionality of the tax and financial support was perhaps the first one.

At the very end, we would like to emphasize the urgent need in Russia of introducing the practice of regular and independent assessments of the effectiveness of public policies. At the same time, in our opinion, one should focus on additionality effects caused by public support, which would not have occurred in its absence. Along with an estimation of input and output effects, it is essential to take also behavioral changes that determine to a large extent the stability of the public support impact on the companies into account. This would help to create the required information basis for decision making on public incentive policies (both existing and to be initiated in the future), and would contribute to learning and scaling of the best practices. 


\section{REFERENCES}

Antonioli, D., Marzucchi A., Montresor, S. (2012) 'Regional innovation policy and innovative behaviours. A propensity score matching evaluation', Ingenio Working Paper, № 5.

Aralicaa, Z., BotriĐ, V. (2013) 'Evaluation of research and development tax incentives sheme in Croatia', Ekonomska Istrazivanja, Economic Research, 26(3), pp. 63-80.

Aschhoff, B. (2009) 'The effect of subsidies on R\&D investment and success: do subsidy history and size matter?' ZEW Discussion Paper, 09-032, Mannheim.

Aschhoff, B. (2010) 'Who gets the money? The dynamics of RgD project subsidies in Germany', Journal of Economics and Statistics, vol. 230(5), pp. 522-46.

Bach, L., Matt, M. (2002) 'Rationale for Science and Technology Policy'. In: Georghiou, L.,Rigby, J., (Eds.) Assessing the Socio-Economic Impacts of the Framework Programme, Report to DG Research.

Baghana, R. (2010) 'Public R\&D Subsidies and Productivity: Evidence from firm level data in Quebec', United Nations University - Maastricht Economic and social Research and training centre on Innovation and Technology, Working paper, August 2010.

Benavente, J., Crespi, G., Maffiolly, A. (2007) ‘Public Support to FirmLevel Innovation: The Evaluation of the FONTEC Program', OVE Working Paper, 0507, Inter-American Development Bank, Office of Evaluation and Oversight (OVE).

Bodas Freitas, I., Castellacci, F., Fontana, R., Malerba, F., Vezzulli, A. (2015) 'The additionality effects of R\&D tax credits across sectors: A cross-country microeconometric analysis', Centre for Technology, Innovation and Culture, University of Oslo, Working paper, March 2015

Buisseret, T., Cameron, H., Georghiou, L. (1995) 'What Difference Does It Make - Additionality in The Public Support Of R\&D In Large Firms', International Journal of Technology Management, № 10.

Busom, I, Fernandez Ribas, A. (2008) 'The impact of firm participation in R\&D programmes on R\&D partnerships', Research Policy, vol. 37(2), pp. 240-57.

Callejón, M., García-Quevedo, J. (2005) 'Public subsidies to business R\&D: Do they stimulate private expenditures?', Environment and Planning C: Government and Policy, 23, pp. 279-93.

Cantner, U., Kösters, S. (2015) 'Public R\&D support for newly founded firms - effects on patent activity and employment growth', Journal of Innovation Economics \& Management, vol. 1(16), pp. 7-37.

Catozzella. A., Vivarelli. M. (2011) 'Beyond Additionality: Are Innovation Subsidies Counterproductive?', Discussion Paper, № 5746.
Chudnovsky, D., Lopez, A., Pupato, G. (2006) 'Innovation and productivity in developing countries: a study of Argentine manufacturing firms' behavior (1992-2001)', Research Policy, 35(2), pp. 266-88.

Clausen, T. (2009) 'Do subsidies have positive impacts on R\&D and innovation activities at the firm level?', Structural Change and Economic Dynamics, 20, pp. 239-53.

Crespi, F., Antonelli, C. (2011) 'Matthew effects and R\&D subsidies: knowledge cumulability in high-tech and low-tech industries', Departmental Working Papers of Economics, University Roma Tre.

Crespi, G., Maffioli A., Mohnen, P., Vazquez, G. (2011) 'Evaluating the Impact of Science, Technology and Innovation Programs: a Methodological Toolkit', SPD Working Papers, 1104, Inter-American Development Bank, Office of Strategic Planning and Development Effectiveness.

Czarnitzki, D., Licht, G. (2006) 'Additionality of public R\&D grants in a transition economy: The case of Eastern Germany', Economics of Transition, 14, pp. 101-31.

David, P., Hall, B., Toole, A. (2000) 'Is Public R\&D a Compliment or a Substitute for Private R\&D? A Review of Econometric Evidence', Research Policy, vol. 29 (4), pp. 497-529.

Falk, R. (2004) 'Behavioural Additionality Effects of R\&D Subsidies: Empirical Evidence from Austria', WIFO Working Paper. Available at: http:// www.fep.up.pt/conferences/earie2005/cd_rom/Session\%20IV/IV.B/ Falk.pdf

Falk, R. (2006) 'Behavioural additionality in Austria's industrial research promotion fund (FFF)'. Chapter 3 in: Government R\&D Funding and Company Behaviour: Measuring behavioural additionality, Paris, OECD, pp. 59-74.

Falk, R. (2007) 'Measuring the effects of public support schemes on Firms innovation activities', Research Policy, vol. 36(5), pp. 665-79.

Fier, A., Heneric, 0. (2005) 'Public R\&D Policy: The Right Turns of the Wrong Screw? The Case of the German Biotechnology Industry', ZEW Discussion Papers, № 05-60.

Fier, A., Aschhoff, B., Löhlein, H. (2006) 'Detecting Behavioural Additionality: An Empirical Study on the Impact of Public R\&D Funding on Firms' Cooperative Behaviour in Germany', ZEW Discussion Papers, № 06-037.

Garcia, A., Mohnen, P. (2010) 'Impact of Government Support on R\&D and innovation', UNU-MERIT Working Paper Series, № 2010-034, United Nations University - Maastricht Economic and Social Research Institute on Innovation and Technology.

Georghiou, L. (1997) 'Issues in the evaluation of innovation and technology policy'. Chapter 3 in: Policy evaluation in innovation and technology: towards best practice, $\mathrm{OECD}$. 
Georghiou, L. (2002) 'Impact and additionality of innovation policy', IWT-Studies, №. 40, pp. 57-67. Available at: http://www.iwt.be/sites/ default/files/english/files/iwt_studie40.pdf

Georghiou, L., Clarysse, B. (2006) 'Introduction and Synthesis'. Chapter 1 in: Government R\&D Funding and Company Behaviour: Measuring behavioural additionality, OECD Publishing, Paris.

Georghiou, L., Malik, K., Cameron, H. (2005). 'DTI Exploratory study on behavioural additionality', PREST, Manchester Business School and University of Manchester, Working paper.

Georghiou, L., Rigby, J., Cameron, H. (eds.) (2002) 'Assessing the Socio-Economic Impacts of the Framework Programme. Report to European Commission DG Research'. Available at: http://ec.europa.eu/research/ evaluations/pdf/archive/other_reports_studies_and_documents/assessing_the_socio_economic_impacts_of_the_framework_programme_2002.pdf

Gelabert, L., Fosfuri, A., Tribó, J.A. (2009) 'Does the effect of public support for $r \& d$ depend on the degree of appropriability?', Journal of Industrial Economics, № 57, pp. 736-67.

Gokhberg, L., Kitova, G., Roud, V. (2014) 'Tax Incentives for R\&D and Innovation: Demand versus Effects', Foresight-Russia, vol. 8(3), pp. 18-41.

Gok, A. (2010) 'An Evolutionary Approach to Innovation Policy Evaluation: Behavioural Additionality and Organisational Routines', PhD Thesis, Manchester Institute of Innovation Research, The University of Manchester. Available at: http://www.innovation-policy.org.uk/compendium/reference/Default.aspx?referenceid $=1026$

Gok, A., Edler J. (2011) 'The Use of Behavioural Additionality in Innovation Policy-Making', MBS/MloIR Working Paper, № 627, The University of Manchester.

González, X., Jaumandreu, J., Pazó, C. (2005) 'Barriers to innovation and subsidy effectiveness', RAND Journal of Economics, №36, pp. 93050.

Guellec D., Van Pottlesberghe, B. (2003) 'The impact of public R\&D expenditure on business R\&D', Economics of Innovation and New Technologies, vol. 12(3), pp. 225-44.

Hægeland, T., Møen, J. (2007) 'Input additionality in the Norwegian R\&D tax credit scheme', Statistics Norway Reports, № 2007/47. Available at: http://www.ssb.no/a/publikasjoner/pdf/rapp_200747/rapp_200747. pdf

Higher School of Economics, Interdepartmental Analytical Center. (2009), Evaluation of Anti-crisis Measures Supporting the Real Sector of the Russian Economy', Voprosy Ekonomiki, vol. 5, pp. 21-46.

Hsu, F.M., Horng, D.J., Hsueh, C.C. (2009) 'The effect of governmentsponsored R\&D programmes on additionality in recipient firms in Taiwan', Technovation, №29, pp. 204-17.
Hottenrott, H., Lopes-Bento, C. (2013) '(International) RqD collaboration and SMEs: The effectiveness of targeted public R\&D support schemes', DICE Discussion Paper, № 121.

Hud, M., Hussinger, K. (2014) 'The Impact of RqD Subsidies During the Crisis', ZEW Discussion Paper, № 14-024.

Idea Consult (2006) 'Study and Evaluation of the Behavioral Additionality of R\&D subsidies'. Available at: http://www.iwt.be/sites/default/ files/english/files/final_report_BA_IWT-subsidies_10_11_2006.pdf

Idea Consult (2009) 'Does Europe change R\&D-behaviour? Assessing the behavioural additionality of the Sixth Framework Programme'. Available at: https://ec.europa.eu/research/evaluations/pdf/archive/ fp6-evidence-base/evaluation_studies_and_reports/evaluation_studies_and_reports_2009/assessing_the_behavioural_additionality_of_ the_sixth_framework_programme.pdf

Jaumotte, F., Pain, N. (2005) 'An Overview of Public Policies to Support Innovation', OECD Economic Department, Working paper, № 456.

Klette, T., Moen, J., Griliches, Z. (2000) 'Do Subsidies to Commercial R\&D Reduce Market Failures? Micro Econometric Evaluation Studies', Research Policy, 29, pp. 471-95.

Knockaert, M., Spithoven, A. (2009) 'When do firm-technology intermediary interactions result in cognitive capacity additionality?', Working Paper, D/2009/7012/61.

Kuzyk, M., Simachev, Yu. (2013) 'Russia's Innovation Promotion Policies: Their Evolution, Achievements, Problems and Lessons'. Chapter 6.4 in: Russian Economy in 2012. Trends and Outlooks (Issue 34) (eds. Sinelnikov-Murylev, S. G.), Moscow: Gaidar Institute Publishers, pp. 435-79.

Lach, S. (2002) ‘Do R\&D Subsidies Stimulate or Displace Private R\&D? Evidence from Israel', Journal of Industrial Economics, L (4), pp. 369-90.

Lohmann, F. (2014) 'The Additionality Effects of Government Subsidies on R\&D and Innovation Activities in the Aviation Industry. A Project Level Analysis', Master's thesis. Available at: http://essay.utwente. nl/64836/1/Lohmann_MA_MB.pdf

Lokshin, B., Mohnen, P. (2012) 'How effective are level-based R\&D tax credits? Evidence from the Netherlands', Applied Economics, vol. 44(12), pp. 1527-38.

Loof, H., Heshmati, A. (2005) 'The Impact of Public Funding on Private R\&D Investment: New Evidence from a Firm Level Innovation Study', MTT Discussion papers, № 3.2005 .

Lucena, A., Afcha, S. (2014) 'Public Support for R\&D, Knowledge Sourcing and Firm Innovation: Examining a Mediated Model with Evidence from the Manufacturing Industries', CENTRUM Católica's Working Paper Series, № 2014-06-0002. 
Marzucchi, A., Montresor, S. (2013) 'The Multi-Dimensional Additionality of Innovation Policies: A Multi-Level Application to Italy and Spain', SPRU Working Paper Series, № 2013-04.

Mau, V. (2010) 'Economic Policy in 2009: Between the Crisis and Modernization', Voprosy Ekonomiki, vol. 2, pp. 4-25.

Merton, R.K. (1968) 'The Matthew effect in science', Science, № 159 (3810).

Montmartin, B., Herrera, M. (2015) 'Internal and external effects of R\&D subsidies and fiscal incentives: Empirical evidence using spatial dynamic panel models', Research Policy, 44(5). pp. 1065-79.

Montmartin, B., Herrera, M., Massard. N. (2015) 'RGD policies in France: New evidence from a NUTS3 spatial analysis', Working Paper GAEL, № 2015-11.

Neicu, D., Teirlinck, P., Kelchtermans, S. (2015) 'Dipping in the policy mix: do R\&D subsidies foster behavioral additionality effects of R\&D tax credits?', Economics of Innovation and New Technology, pp. 1-22. Available at: https://lirias.kuleuven.be/bitstream/123456789/445812/1/ MSI_1409.pdf

Newey, Whitney K. (2009) 'Treatment effects', Quantile, №. 6, pp. 15-23.

OECD (2006) 'Government R\&D Funding and Company Behaviour, Measuring Behavioural Additionality'. Available at: http://browse.oecdbookshop.org/oecd/pdfs/product/9206041e.pdf

OECD (2015) ‘OECD Science, Technology and Industry Scoreboard 2015: Innovation for growth and society', OECD Publishing, Paris.

Pegler, B. (2005) 'Behavioural Additionality in Australian Business R\&D Grant Programs: A Pilot Study', Department of Industry, Tourism and Resources, Working paper.

Polt, W., Streicher, G. (2005) 'Trying to capture additionality in Framework Programme 5 - main findings', Science and Public Policy, 32(5), pp. 367-73.

Poot, T., Hertog, P., Grosfeld, T., Brouwer, E. (2003) 'Evaluation of a major Dutch Tax Credit Scheme (WBSO) aimed at promoting R\&D', Discussion Paper. Available at: http://ftp.zew.de/pub/zew-docs/ evaluationR\%26D/EBrouwer.pdf

Rodrik, D. (2008) 'The New Development Economics: We Shall Experiment, but How Shall We Learn?', Harvard University, John F. Kennedy School of Government, Working Paper Series, № rwp08-055.

Roper, S., Hewitt-Dundas, N. (2012) 'Does additionality persist? A panel data investigation of the legacy effects of public support for innovation', Available at: http://druid8.sit.aau.dk/acc_papers/u7flocbh7rlj5s6uof3gkgquivxo.pdf
Rye, M. (2002) 'Evaluating the Impact of Public Support on Commercial Research and Development Projects: Are Verbal Reports of Additionality Reliable?', Evaluation, №8(2), pp. 227-48.

Simachev, Yu, Kuzyk, M. (2010) 'State guarantee support of strategic companies as Russian anti-crisis policy tool: specifics, problems and lessons for the future', Jekonomicheskaja politika, № 3, pp. 6489.

Simachev, Yu, Kuzyk, M. (2015) 'State policy to promote scientific and industrial cooperation'. Chapter 6.4 in: Russian economy in 2014. Trends and outlooks. (Issue 36) (eds. Sinelnikov-Murylev, S. G.), Moscow: Gaidar Institute Publishers, 2015, pp.m465-511.

Simachev, Yu., Kuzyk, M., Feygina, V. (2014a) 'Fostering firms' innovation activities in Russia. Empirical analysis of beneficiaries and effects'. In Yasin, Ev.G (Ed) (2014) XIV April International Academic Conference on Economic and Social Development, vol. 3, pp. 369-88.

Simachev, Yu., Kuzyk, M., Feygina, V. (2014b) 'Public Support for Innovation in Russia: What Can We Say about Tax Incentives and Public Funding?', Russian Management Journal, vol. 12(1), pp. 7-38.

Simachev, Yu., Kuzyk, M., Feygina, V. (2014c) 'R\&D Cooperation between Russian Firms and Research Organizations: Is There a Need for State Assistance?', Voprosy Ekonomiki, vol. 5, pp. 4-34.

Simachev, Yu., Kuzyk, M., Feygina V. (2015) 'Public Support for Innovation in Russian Firms: Looking for Improvements in Corporate Performance Quality', International Advances in Economic Research, № 21(1), pp. 13-31.

Simachev, Yu., Kuzyk, M., Ivanov, D. (2012) 'Instruments of government support for innovative companies in Russia: beneficiaries and issues'. In: Znaczenie innowacji dla konkurencyjności międzynarodowej gospodarki. (eds. Rynarzewski, T., Mińska-Struzik, E.), Poznan: Wydawnictwo Uniwersytetu Economicznego w Poznaniu, pp. 183-201.

Simachev, Yu., Kuzyk, M., Ivanov D. (2012) 'Russian Financial Development Institutions: Are We on the Right Way?', Voprosy Ekonomiki, vol. 7. pp. 4-29.

Simachev, Yu, Kuzyk, M., Kuznetsov, B. (2010) 'Assessing the impact of various anti-crisis measures on the firms in manufacturing industries', Jekonomicheskaja politika, №1, pp. 122-134.

Viljamaa, K., Piirainen, K., Kotiranta, A., Karhunen, H., Huovari, J. (2013) 'Impact of Tekes activities on productivity and renewal'. Available at: http://www.tekes.fi/globalassets/global/nyt/uutiset/productivityand-renewal-2013.pdf

Wallsten, S. (2000) 'The Effects of Government-Industry R\&D Programs on Private R\&D: The Case of the Small Business Innovation Research Program', RAND Journal of Economics, 31, pp. 82-100. 
Wanzenbock, I., Scherngell T., Fischer, M. (2013) 'How do firm characteristics affect behavioural additionalities of public R\&D subsidies?', Technovation, vol. 33 (2-3), pp. 66-77.

Zudin, N. (2015) 'Relationship of the technology level of sector with company characteristics and public support', Innovations, №6, pp. 61-70.

\section{AUTHORS}

\section{YURI SIMACHEV}

National Research University Higher School of Economics

20 Myasnitskaya str., 101000 Moscow, Russian Federation

\section{MIKHAIL KUZYK}

Interdepartmental Analytical Center

P.0. Box 35, 31/29 Povarskaya str., 121069 Moscow, Russian Federation

corresponding author:

\section{NIKOLAY ZUDIN}

Center for Strategic Research

10 Vozdvizhenka str., 125009 Moscow, Russian Federation

$\mathrm{T}:+79165715843$

E: N zud@mail.ru 